\title{
DESCRIÇÃO MORFOLÓGICA DOS PRIMEIROS ESTÁGIOS LARVAIS DE LEPTALPHEUS FORCEPS (DECAPODA, ALPHEIDAE), CULTIVADO IN VITRO, E NOVA OCORRÊNCIA PARA O LITORAL BRASILEIRO
}

\author{
Rosário, T.N. ${ }^{1,}{ }^{,}$; Pires, M.A.B. ${ }^{1}$; Souza, A.S. ${ }^{1}$; Abrunhosa, F.A. ${ }^{1}$ \& Simith, D.J.B. ${ }^{1}$ \\ ${ }^{1}$ Universidade Federal do Pará (UFPA), Campus Universitário de Bragança, Instituto de Estudos Costeiros (IECOS), \\ Laboratório de Carcinologia. Alameda Leandro Ribeiro s/n, Aldeia, 68600-000, Bragança, Pará, Brasil.
}

*Autor correspondente: tayse_nascimento@hotmail.com

\begin{abstract}
No presente estudo, a morfologia dos primeiros estágios de zoea (ZI-ZV) de Leptalpheus forceps Williams, 1965 foi descrita e ilustrada em detalhes. As características morfológicas das larvas no estágio ZI dessa espécie foram ainda comparadas com aquelas das larvas de Alpheus estuariensis Christoffersen, 1984, única espécie simpátrica com larvas descritas na literatura. Este estudo também representa um novo registro de ocorrência de L. forceps para o litoral brasileiro, do qual espécimes machos, fêmeas ovígeras e não ovígeras foram encontrados habitando as tocas do camarão callianassídeo Lepidophthalmus siriboia Felder \& Rodrigues, 1993, no estuário do Rio Caeté, Estado do Pará. Fêmeas ovígeras $(n=54)$ foram transportadas ao laboratório e foram mantidas em recipientes $\left(500 \mathrm{~mL}\right.$ ) separados contendo água do mar filtrada com temperatura ambiente de $27,8 \pm 0,4{ }^{\circ} \mathrm{C}$, salinidade 30,1 $\pm 0,8, \mathrm{pH} 8,2 \pm 0,7$, com aeração moderada, em regime de $12 \mathrm{~h}$ luz/12 h escuro e alimentadas com náuplios de Artemia salina (Linnaeus, 1758) até o nascimento das larvas. Após a eclosão, as larvas foram cultivadas nas mesmas condições abióticas, porém em nove tratamentos com sete espécies de microalgas, uma espécie de rotífero e náuplios recém-eclodidos de $A$. salina, testados separadamente como item alimentar, e em um tratamento sem alimento. Cada tratamento foi realizado em 5 réplicas, onde as larvas foram cultivadas em placas de Petri $(50 \mathrm{~mL}$ ) contendo 30 indivíduos cada. As larvas de L. forceps se desenvolveram até o estágio ZV, independente da presença ou tipo de alimento testado, havendo total mortalidade das larvas neste estágio. A duração dos estágios de zoea ( $Z I=8,4 \pm 2,1$ h; ZII = 22,7 $\pm 6,2$ h; ZIII = 42,9 $\pm 10,6$ h; ZIV = 26,7 $\pm 6,1$ h) não apresentou diferenças entre os tratamentos. O estágio ZI de $L$. forceps se diferencia das larvas de $A$. estuariensis por não apresentar espinho pterigostomial na carapaça e possuir exópodo da antena com 6 segmentos, endito basal da maxila bilobado, e protópodo do $1^{\circ} \mathrm{e} 2^{\circ}$ maxilípedes com 2 espinhos. A presença, quantidade, disposição e tipos de cerdas em alguns apêndices também variam entre as duas espécies. Os resultados mostraram que os primeiros estágios de zoea de $L$. forceps são lecitotróficos e sugerem que esta espécie pode apresentar um comportamento planctotrófico, ao se desenvolver para zoea $\mathrm{V}$, exigindo um ou mais tipos de alimentos específicos e/ou condições abióticas mais favoráveis que permitam o seu desenvolvimento até a fase juvenil.
\end{abstract}

Palavras-chave: Alpheidae, desenvolvimento larval, Leptalpheus, larvas de Decapoda, zoea. 